\title{
Pengaruh Substitusi Tepung Kedelai (Glicine max) dengan Tepung Daun Kelor (Moringa oleifera, Lam) terhadap Pertumbuhan dan Kelangsungan Hidup Ikan Bandeng (Chanos chanos)
}

\section{The effect of substitution of soybean (Glycine max) meal with moringa (Moringa oleifera ) leaf meal on the growth and survival rate of milk fish (Chanos chanos)}

\author{
Anshar $^{1 *)}$, Muhaimin Hamzah ${ }^{2)}$, Wellem H. Muskita ${ }^{2)}$, Agus Kurnia ${ }^{2)}$ \\ ${ }^{1)}$ Program Studi Ilmu Perikanan PPs Univ. Halu Oleo, Kendari, Indonesia \\ 2) Fakultas Perikanan dan Ilmu Kelautan Universitas Halu Oleo, Kendari, Indonesia \\ Corresponding autors ${ }^{*}$ : ansharefka@yahoo.com
}

\begin{abstract}
This study aimed to determine the effect of substitution of soybean (Glycine max) meal with moringa (Moringa oleifera) leaf meal on the growth and survival rate of milk fish (Chanos chanos). The fish used in this experiment was milk fish with initial weight $2 \pm 0,5 \mathrm{~g}$. Four experimental diets were formulated to contain different subtitution of soybean meal (SM) with moringa leaf meal (MM). Diet 1 contained $100 \% \mathrm{SM}+0 \%$ MM, Diet 2 contained 75\% SM + 25\% MM, Diet 3 contained 50\% SM + 50\% MM and Diet 4 contained 25\% $\mathrm{SM}+75 \% \mathrm{MM}$ in the diet. The fish were reared in 12 glass tanks with designed by using recirculating system and filled with filtered sea water (water salinity: $25 \pm 2 \mathrm{ppt}$ ). The fish were fed with experimental diet in twice a day (08.00 a.m and 04.00 p.m) for 40 days of rearing. Some parameters determined were weight gain, specific growth rate (SGR), survival rate (SR), feed convertion ratio (FCR), feed efficiency (FE), feed consumption (FC), and protein retention (PR). The results showed that weight gain and SGR of fish fed the diet were ranged between $52,22-61,34 \mathrm{~g}$ and 3,13-3,32\%, respectively. SR of fish were ranged between 96,67 -100\%. FCR and FE of milk fish were ranged between $2,75-2,81$ and $35,79-37,42 \%$, respectively. FC and PR of fish were ranged between $145,69-164,39 \mathrm{~g}$ and $16,58-18,48 \%$, respectively. The water quality of fish during feeding trial were optimum for milk fish rearing.
\end{abstract}

Keywords : substitution, growth, soybean meal, moringa leaf meal, milk fish.

\begin{abstract}
ABSTRAK
Penelitian ini bertujuan untuk mengetahui pengaruh substitusi tepung kedelai (TK) dengan tepung daun kelor $(T D K)$ terhadap pertumbuhan dan kelangsungan hidup ikan bandeng. Hewan uji yang digunakan adalah ikan bandeng ukuran $2 \pm 0,5 \mathrm{~g}$. Wadah penelitian adalah akuarium berukuran $60 \times 50$ x $40 \mathrm{~cm}$ yang didesain dengan sistem resirkulasi. Media penelitian adalah air laut bersalinitas $25 \pm 2$ ppt. Penelitian ini dilakukan selama 40 hari, dengan diberi pakan uji sesuai perlakuan. Penyiponan dilakukan setiap pagi hari sebelum diberi pakan agar kualitas air dapat dipertahankan. Pengamatan kualitas air dilakukan setiap hari untuk parameter salinitas, suhu, $\mathrm{pH}$, sedangkan untuk kandungan oksigen terlarut, amoniak, dilakukan pada awal, tengah dan akhir penelitian. Penelitian ini didesain dengan menggunakan rancangan acak lengkap dengan mengaplikasikan 4 perlakuan dan 3 ulangan. Perlakuan yang diterapkan adalah A(100\% TK + 0\% TDK), B (75\% TK + 25\% TDK), C (50\% TK + $50 \%$ TDK) dan D $(25 \%$ TK $+75 \%$ TDK). Parameter yang diamati adalah pertumbuhan mutlak, laju pertumbuhan harian, kelangsungan hidup, rasio konversi pakan, efisiensi pakan, konsumsi pakan dan retensi protein. Hasil penelitian menunjukkan bahwa pertumbuhan mutlak yang didapatkan berkisar antara 52,22 $61,34 \mathrm{~g}$, laju pertumbuhan harian berkisar 3,13 - 3,32\%, tingkat kelangsungan hidup berkisar 96,67 - 100\%,
\end{abstract}


rasio konversi pakan berkisar 2,75 - 2,81, efisiensi pakan berkisar 35,79-37,42\%, konsumsi pakan berkisar 145,69 - 164,39 g, retensi protein berkisar 16,58 - 18,48\%. Hasil pengukuran parameter kualitas air selama penelitian berada dalam kisaran yang dapat ditolerir oleh ikan bandeng.

Kata kunci : Substitusi, tepung daun kelor, tepung kedelai, ikan bandeng, pertumbuhan

\section{DOI: http://dx.doi.org/10.33772/jspi.v2n2.}

\section{PENDAHULUAN}

Ikan bandeng merupakan salah satu komoditas yang strategis untuk memenuhi kebutuhan protein konsumen. Bandeng sebagai bahan pangan, merupakan sumber zat gizi bagi manusia. Pamijati (2009) menyatakan bahwa ikan bandeng digemari oleh sebagian besar masyarakat karena memiliki gizi. Zat gizi utama pada ikan antara lain protein, lemak, vitamin dan mineral.

Dalam usaha budidaya ikan baik semi intensif maupun intesif, pakan merupakan faktor yang sangat berpengaruh terhadap pertumbuhan. Hal ini disebabkan pakan sebagai sumber protein, untuk pertumbuhan ikan. Untuk itu dalam pakan harus memiliki kandungan protein yang diperlukan bagi ikan. Protein merupakan nutrien yang sangat dibutuhkan dalam pertumbuhan ikan, karena protein sebagai komponen terbesar dari daging dan berfungsi sebagai bahan pembentuk jaringan tubuh (Halver, 1989).

Selama ini sumber protein yang digunakan dalam pakan buatan adalah sumber protein hewani dari tepung ikan dan protein nabati dari kedelai. Kedua bahan tersebut masih diimpor, sehingga menyebabkan biaya pakan tinggi (Suprayudi, 2010). Untuk mengatasi hal tersebut maka dicari sumber protein nabati yang mirip atau mendekati nilai nutrisi tepung kedelai.

Funglie (2001) menyebutkan bahwa dalam berat yang sama, daun segar kelor mengandung vitamin $\mathrm{C}$ 7 kali lebih banyak dibanding jeruk, vitamin A 4 kali lebih banyak dibanding wortel, kalsium 4 kali lebih banyak dibanding susu (tanpa laktosa), kalium 3 kali lebih banyak dibanding pisang, protein 2 kali lebih banyak dibanding yoghurt, zat besi 25 kali lebih banyak dibanding bayam.

Asam amino esensial adalah asam amino yang tidak dapat diproduksi dalam tubuh dan harus diperoleh dari makanan sumber protein yang disebut juga asam amino eksogen. Asam amino seringkali disebut dan dikenal sebagai zat pembangun yang merupakan hasil akhir dari metabolisme protein. Puycha et al. (2017) menyatakan bahwa daun kelor sebagai sumber protein tanaman dapat digunakan untuk suplemen dalam mendukung pertumbuhan tanpa memberikan pengaruh buruk pada kecernaan ikan lele.Sampaisaatini, penggunaan tepung daun kelor sebagai pakan untuk ikan air laut khususnya ikan bandeng belum dilakukan.Oleh sebab itu dilakukan penelitan tentang pengaruh substitusi tepung kedelai (Glycine max) dengan tepung daun kelor (Moringa oleifera, Lam) terhadap pertumbuhan, retensi protein dan komposisi asam amino esensial ikan bandeng (Chanos chanos).

Penelitian ini bertujuan untuk mengetahui pengaruh substitusi tepung kedelai (Gycine max) dengan tepung daun kelor ( $M$. oleifera, Lam) terhadap pertumbuhan, retensi protein dan komposisi asam amino esensial ikan bandeng (C. chanos).

\section{METODE PENELITIAN}

Penelitian ini dilaksanakan mulai bulan Februari sampai dengan Agustus 2018 di Laboratorium Pembenihan dan Produksi Ikan Fakultas Perikanan dan Ilmu Kelautan Universitas Halu Oleo Kendari. Analisa prosimat dilakukan di PT. Saraswanti, Bogor, sedangkan kualitas air dianalisa di Laboratorium Pengujian FPIK UHO Kendari

Wadah yang digunakan dalam penelitian ini adalah akuarium berukuran $60 \times 50 \times 40 \mathrm{~cm}$ yang dirancang menggunakan sistem resirkulasi. Akuarium diisi air laut yang sudah disterilisasi sebanyak 90 liter. Air laut yang digunakan berasal dari BBU Mata dengan salinitas $25 \pm 2$ ppt dan diberi aerasi. Lalu dimasukkan ikan bandeng sebanyak 10 ekor setiap akuarium.

Ikan uji yang digunakan dalam penelitian ini adalah ikan bandeng yang berasal dari pembenihan ikan bandeng Gondol Bali dengan bobot $2 \pm 0,5 \mathrm{~g}$. Sebelum dilakukan percobaan terlebih dahulu ikan diadaptasikan, dengan cara diberikan pakan komersil 
42 Anshar et al.

JURNAL SAINS dan INOVASI PERIKANAN/ Journal of Fishery Science and Innovation

Vol. 2, No. 2, 40-48, Juli 2018

selama 7 hari sebagai proses adaptasi terhadap kondisi lingkungan percobaan.

Pakan uji yang digunakan dalam penelitian ini adalah pakan buatan berbentuk pelet dengan protein target 33\%. Formulasi pakan uji disajikan pada Tabel 1.

Tabel 1. Formulasi pakan uji berdasarkan perlakuan

\begin{tabular}{lcccc}
\hline \multirow{2}{*}{ Bahan Baku } & \multicolumn{4}{c}{ Komposisi Pakan Uji Setiap } \\
\cline { 2 - 5 } & A & B & C & D \\
\hline Tepung Ikan & 22 & 22 & 22 & 22 \\
Tembang & & & & \\
Tepung Udang & 22 & 22 & 22 & 22 \\
Tepung Kedelai & $\mathbf{2 5}$ & $\mathbf{1 8 , 7 5}$ & $\mathbf{1 2 ,}$ & $\mathbf{6 , 2 5}$ \\
(TK) & & & $\mathbf{5}$ & \\
Tepung Daun Kelor & $\mathbf{0}$ & $\mathbf{6 , 2 5}$ & $\mathbf{1 2 ,}$ & $\mathbf{1 8 , 7 5}$ \\
(TDK) & & & $\mathbf{5}$ & \\
Tepung Jagung & 11 & 11 & 11 & 11 \\
Tepung Dedak Halus & 11 & 11 & 11 & 11 \\
Tepung Tapioka & 4,5 & 4,5 & 4,5 & 4,5 \\
Tepung Sagu & 3 & 3 & 3 & 3 \\
Minyak Ikan & 0,5 & 0,5 & 0,5 & 0,5 \\
Minyak cumi & 0,5 & 0,5 & 0,5 & 0,5 \\
TOP MIX & 0,5 & 0,5 & 0,5 & 0,5 \\
\hline TOTAL & $\mathbf{1 0 0}$ & $\mathbf{1 0 0}$ & $\mathbf{1 0 0}$ & $\mathbf{1 0 0}$ \\
\hline
\end{tabular}

Pemeliharan ikan dilakukan selama 40 hari. Selama pemeliharaan, ikan diberi pakan sebanyak 2 kali sehari yakni pada pukul 07.00 dan 17.00 WITA. Pakan diberikan secara adlibitum atau sampai kenyang. Sisa pakan diambil setelah pemberian pakan, selanjutnya dikeringkan dan ditimbang sebagai dasar menghitung efisiensi pakan. Penyiponan dilakukan setiap hari agar sisa pakan maupun sisa metabolisme dapat dikeluarkan.

Sistem pemeliharaan dilakukan secara resirkulasi pada wadah akuarium dengan pengontrolan pada penampungan air. Pengukuran kualitas air meliputi suhu air menggunakan termometer dan salinitas menggunakan hand refraktometer. Pengukuran suhu, $\mathrm{pH}$, dan salinitas dilakukan tiap hari. Pengambilan sampel oksigen terlarut, amoniak, nitrat, nitrit, dan phosfat dilakukan awal, tengah dan akhir penelitian. Pengukuran berat ikan dilakukan diawal dan akhir penelitian.

Penelitian ini didesaindenganmenggunakan rancangan acak lengkap (RAL)dengan 4 perlakuan dan 3 ulangan. Perlakuan yang digunakan adalah : perlakuan $\mathrm{A}=100 \% \mathrm{TK}$ dan $0 \% \mathrm{TDK} ; \mathrm{B}=75 \% \mathrm{TK}$ dan 25\% TDK; $\mathrm{C}=50 \%$ TK dan 50\% TDK; $\mathrm{C}=$ $25 \%$ TK dan $75 \%$ TDK.

\section{Parameter yang diuji}

\section{Pertumbuhan mutlak}

Perhitungan pertumbuhan mutlak berdasarkan bobot tubuh digunakan rumus Soltanzadeh (2015) yaitu:

$$
P M=\mathrm{Wt}-\mathrm{W} 0
$$

Keterangan:

PM : Pertumbuhan mutlak (g)

Wt : Biomassa ikan pada waktu $\mathrm{t}(\mathrm{g})$

$\mathrm{W}_{0}$ : Bimassa ikan pada awal penelitian $(\mathrm{g})$

\section{Laju pertumbuhan harian}

Laju pertumbuhan harian dihitung berdasarkan formula NRC (1977):

$$
\alpha=\left(t \sqrt{\frac{w t}{w o}}-1\right) \times 100
$$

Keterangan:

$\alpha \quad=$ Laju pertumbuhan harian (\%)

$\mathrm{Wt}=$ Biomassa ikan pada waktu $\mathrm{t}(\mathrm{g})$

Wo $=$ Bimassa ikan pada awal $(\mathrm{g})$

$\mathrm{t}=$ Lama penelitian (hari)

\section{Tingkat kelangsungan hidup}

Tingkat kelangsungan hidup dihitung mengunakan rumus dari Soltanzadeh (2015):

Keterangan:

$$
\mathrm{SR}=\frac{\mathrm{Nt}}{\mathrm{No}} \mathrm{x} \quad 100 \%
$$

SR = Tingkat kelangsungan hidup (\%)

$\mathrm{Nt}=$ Jumlah ikan pada akhir penelitian (ekor)

No = Jumlah ikan pada awal penelitian (ekor)

\section{Rasio konversi pakan}

Rasio Konversi Pakan dihitung menggunakan rumus yang dikemukakan oleh Soltanzadeh (2015):

Keterangan :

$$
\mathrm{FCR}=\frac{\mathrm{F}}{\mathrm{Wt}-\mathrm{Wo}}
$$

$\mathrm{FCR}=$ Rasio konversi pakan

$\mathrm{F} \quad=$ Jumlah pakan yang diberikan $(\mathrm{g})$

$\mathrm{Wt}=$ Bobot pada akhir penelitian $(\mathrm{g})$

Wo = Bobot awal $(\mathrm{g})$ 


\section{Konsumsi pakan}

Jumlah pakan yang dikonsumsi perhari dihitung berdasarkan jumlah pakan yang dimakan (g) dalam sehari dengan jumlah ikan (Bores et al., 2006).

\section{Retensi protein}

Retensi protein dihitung dengan menggunakan rumus yang dikemukakan oleh Takeuchi (1988):

Keterangan:

$$
\mathrm{RP}=\frac{F-I}{P} X 100 \%
$$

$\mathrm{RP}=$ Retensi protein $(\%)$

$\mathrm{F}=$ Bobot protein tubuh ikan pada akhir penelitian (g)

I = Bobot protein tubuh ikan pada awal penelitian $(\mathrm{g})$

$\mathrm{P} \quad=$ Bobot protein yang dikonsumsi $(\mathrm{g})$

\section{Analisis data}

Data pertumbuhan mutlak, laju pertumbuhan harian, kelangsungan hidup, rasio konversi pakan, konsumsi pakan, dan retensi proteindianalisis dengan menggunakan analisis ragam (ANOVA) dengan bantuan program SPSS versi 21.0 for Windows. Jika terdapat perbedaan yang nyata maka dilanjutkan dengan uji Duncan. Kualitas air dianalisis secara deskripsi.

\section{HASIL DAN PEMBAHASAN}

Hasil

Rata-rata pertumbuhan mutlak ikan bandeng $(C$. chanos) selama penelitian disajikan pada Gambar 1.

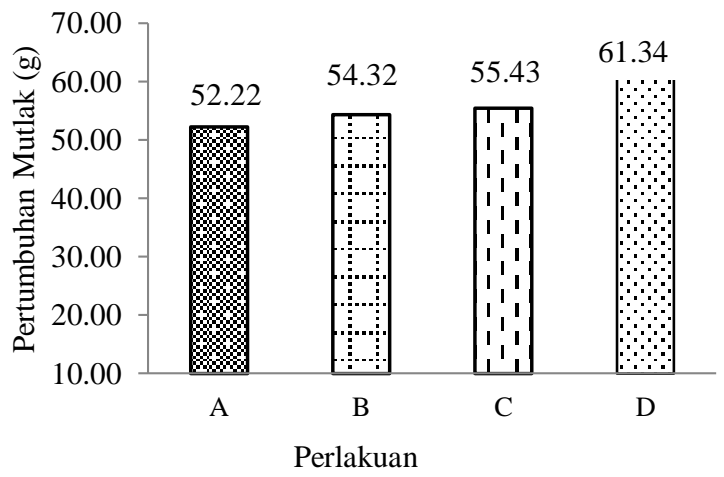

Gambar 1. Rata-rata pertumbuhan mutlak ikan bandeng yang dipelihara selama penelitian. Keterangan perlakuan pemberian pakan A (100\% $\mathrm{TK}+0 \% \mathrm{TDK}) ; \mathrm{B}(75 \% \mathrm{TK}+25 \% \mathrm{TDK}) ; \mathrm{C}(50$ $\% \mathrm{TK}+50 \% \mathrm{TDK})$ dan $\mathrm{D}(25 \% \mathrm{TK}+75 \% \mathrm{TDK})$.
Pada Gambar 1 terlihat bahwa pertumbuhan mutlak cenderung mengalami peningkatan dengan makin meningkatnya penambahan tepung daun kelor dalam pakan. Pertumbuhan mutlak tertinggi didapatkan pada ikan yang diberi pakan perlakuan D $(25 \% \mathrm{TK}+75 \% \mathrm{TDK})$ yaitu sebesar $61,34 \pm 11,20 \mathrm{~g}$, diikuti oleh perlakuan C (50\% TK + 50\% TDK) yaitu sebesar 55,42 $\pm 12,50 \mathrm{~g}$, perlakuan $\mathrm{B}(75 \% \mathrm{TK}+$ $25 \%$ TDK) yaitu sebesar 54,32 $\pm 3,63 \mathrm{~g}$, dan terendahdidapatkanpadaikan yang diberi pakan perlakuan A (100\% TK + 0\% TDK) yaitu sebesar $52,22 \pm 5,09$ g. Hasil analisis ragam menunjukkan bahwa pakan uji yang diberikan tidak memberikan pengaruh yang berbeda nyata terhadap pertumbuhan mutlak ikan bandeng $(\mathrm{P}>0.05)$.

\section{Laju pertumbuhan harian}

Rata-rata laju pertumbuhan harian ikan bandeng (C. chanos) selama penelitian disajikan pada Gambar 2.

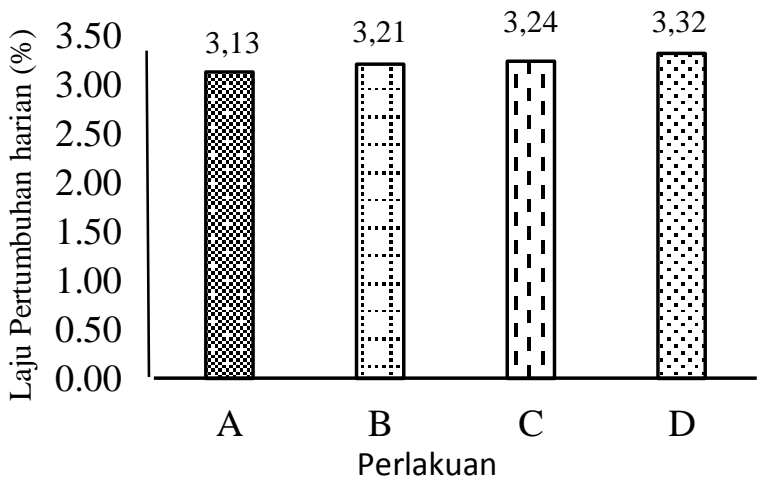

Gambar 2. Rata-rata laju pertumbuhan harian ikan bandeng yang dipelihara selama penelitian. Keterangan pakan A $(100 \%$ TK + 0\% TDK); B $(75 \%$ $\mathrm{TK}+25 \% \mathrm{TDK}) ; \mathrm{C}(50 \% \mathrm{TK}+50 \% \mathrm{TDK})$ dan D $(25 \% \mathrm{TK}+75 \% \mathrm{TDK})$.

Pada Gambar 2 terlihat bahwa laju pertumbuhan harian cenderung mengalami peningkatan dengan makin meningkatnya penambahan tepung daun kelor dalam pakan. Ikan yang diberi pakan perlakuan $\mathrm{D}$ $(25 \% \mathrm{TK}+75 \%$ TDK $)$ yaitu sebesar $3,32 \pm 0,34 \%$, diikuti oleh perlakuan C (50\% TK + 50\% TDK) yaitu sebesar 3,24 $\pm 0,36 \%$, perlakuan B $(75 \% \mathrm{TK}+25 \%$ TDK) yaitu sebesar 3,21 $\pm 0,05 \%$, dan terendah didapatkan pada ikan yang diberi pakan perlakuan A $(100 \%$ TK $+0 \%$ TDK) yaitu sebesar 3,13 $\pm 0,25 \%$. Hasil analisis ragam menunjukkan bahwa pakan uji 
44 Anshar et al.

JURNAL SAINS dan INOVASI PERIKANAN/ Journal of Fishery Science and Innovation

Vol. 2, No. 2, 40-48, Juli 2018

yang diberikan tidak memberikan pengaruh yang berbeda nyata terhadap laju pertumbuhan harian ikan bandeng $(\mathrm{P}>0.05)$.

\section{Kelangsungan hidup}

Rata-rata tingkat kelangsungan hidup ikan bandeng (C. chanos) selama penelitian disajikan pada Gambar 3.

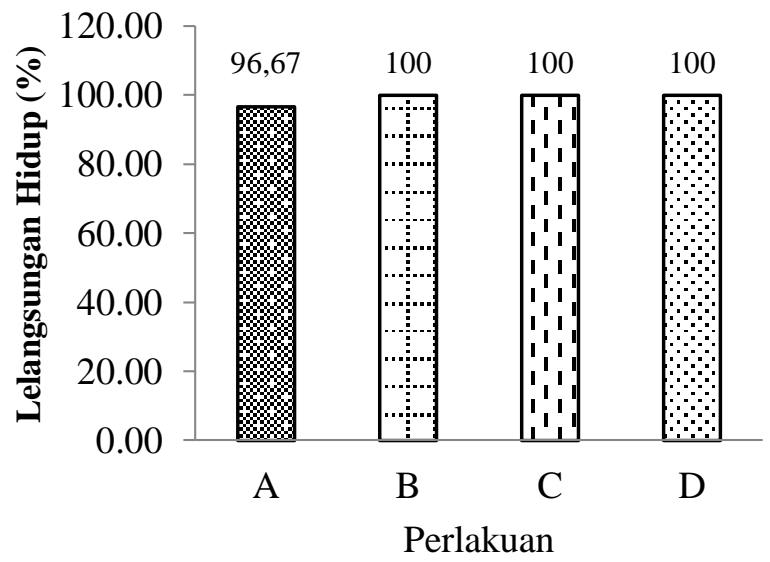

Gambar 3. Rata-rata tingkat kelangsungan hidup ikan bandeng yang dipelihara selama penelitian. Keterangan : A $(100 \%$ TK + 0\% TDK), B (75\% TK $+25 \% \mathrm{TDK}), \mathrm{C}(50 \% \mathrm{TK}+50 \% \mathrm{TDK}), \mathrm{D}(25 \% \mathrm{TK}$ $+75 \%$ TDK).

Pada Gambar 3 terlihat bahwa tingkat kelangsungan hidup ikan uji mencapai $100 \%$ seiring dengan meningkatnya penambahan tepung daun kelor dalam pakan yaitu ikan yang diberi pakan perlakuan A yaitu sebesar $96,67 \pm 5,77 \%$,ikan yang diberi pakan perlakukan B (75\% TK + 25\% TDK), C (50\% $\mathrm{TK}+50 \% \mathrm{TDK}), \mathrm{D}(25 \% \mathrm{TK}+75 \% \mathrm{TDK})$ masingmasing sebesar $100 \%$. Hasil analisis ragam menunjukkan bahwa pakan uji yang diberikan tidak memberikan pengaruh yang berbeda nyata terhadap tingkat kelangsungan hidup ikan bandeng $(\mathrm{P}>0.05)$.

\section{Rasio Konversi Pakan}

Hasil perhitungan rasio konversi pakan ikan bandeng (C. chanos) selama penelitian disajikan pada Gambar 4.

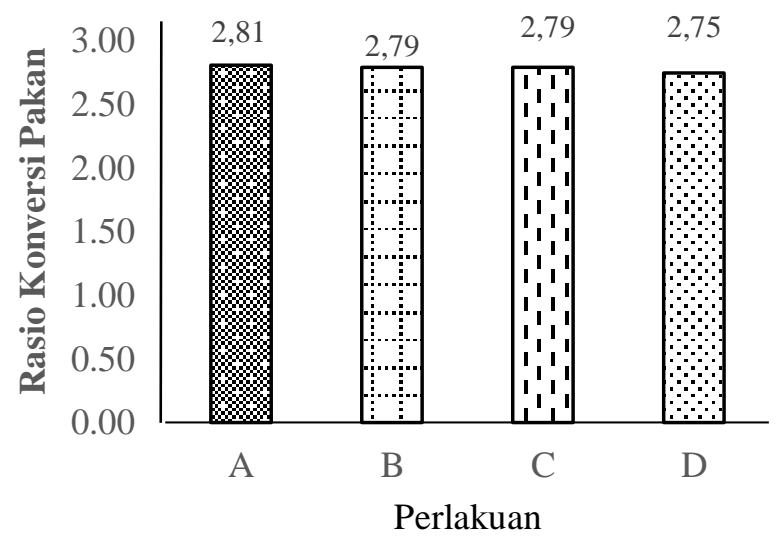

Gambar 4. Rata-rata rasio konversi pakan ikan bandeng yang dipelihara selama penelitian. Keterangan : A (100\% TK + 0\% TDK), B (75\% TK $+25 \% \mathrm{TDK}), \mathrm{C}(50 \% \mathrm{TK}+50 \% \mathrm{TDK}), \mathrm{D}(25 \% \mathrm{TK}$ $+75 \%$ TDK.

Pada Gambar 4 terlihat bahwa rasio konversi pakan cenderung mengalami penurunan dengan meningkatnya penambahan tepung daun kelor dalam pakan. Ikan yang diberi pakan perlakuan A $(100 \%$ TK $+0 \%$ TDK) yaitu $2,81 \pm 0,27$, diikuti oleh perlakuan B $(75 \% \mathrm{TK}+25 \% \mathrm{TDK})$ yaitu $2,79 \pm$ 0,10 , perlakuan C $(50 \% \mathrm{TK}+50 \% \mathrm{TDK})$ yaitu $2,79 \pm$ 0,69 , dan perlakuan D $(25 \% \mathrm{TK}+75 \% \mathrm{TDK})$ yaitu $2,75 \pm 0,55$. Hasil analisis ragam menunjukkan bahwa pakan uji tidak memberikan pangaruh yang berbeda nyata terhadap rasio konversi pakan $(\mathrm{P}>0.05)$.

\section{Konsumsi pakan}

Rata-rata konsumsi pakan ikan bandeng ( $C$. chanos) selama penelitian disajikan pada Gambar 5.

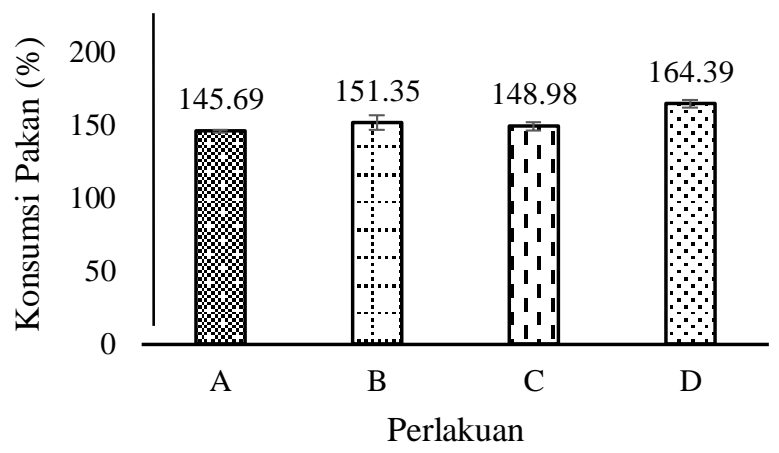

Gambar 5. Rata-rata konsumsi pakan ikan bandeng yang dipelihara selama penelitian Keterangan : A 
$(100 \% \mathrm{TK}+0 \% \mathrm{TDK}), \mathrm{B}(75 \% \mathrm{TK}+25 \% \mathrm{TDK}), \mathrm{C}$ $(50 \% \mathrm{TK}+50 \% \mathrm{TDK}), \mathrm{D}(25 \% \mathrm{TK}+75 \% \mathrm{TDK})$.

Pada Gambar 5 terlihat bahwa tingkat konsumsi pakan mengalami peningkatan pada perlakuan B $(75 \% \mathrm{TK}+25 \% \mathrm{TDK})$ yaitu $151,35 \pm 4,99 \mathrm{~g}$ dibanding perlakuan A (100\% TK + 0\% TDK) yaitu $145,69 \pm 0,99 \mathrm{~g}$, kemudian menurun pada perlakuan $\mathrm{C}(50 \% \mathrm{TK}+50 \% \mathrm{TDK})$ yaitu $148,98 \pm 2,66 \mathrm{~g}$, dan meningkat lagi pada perlakuan D $(25 \% \mathrm{TK}+75 \%$ TDK) yaitu $164,39 \pm 2,63$ g. Hasil analisis ragam menunjukkan bahwa pakan uji yang diberikan memberikan pengaruh yang berbeda nyata terhadap tingkat konsumsi pakan $(\mathrm{P}<0.05)$.

\section{Retensi protein}

Rata-rata retensi protein ikan bandeng $(C$. chanos) selama penelitian disajikan pada Gambar 6 .

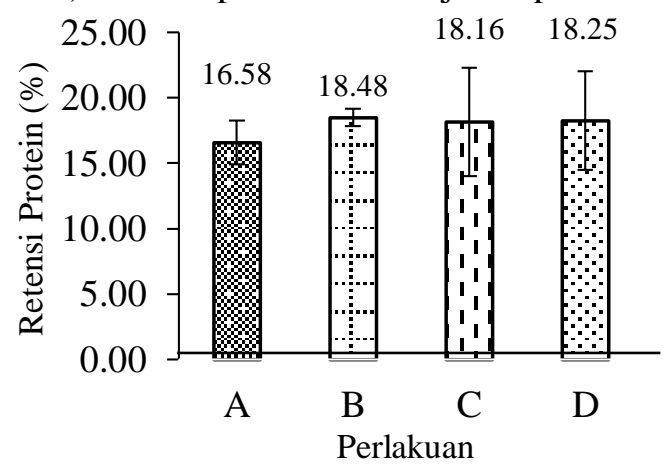

Gambar 6. Rata-rata retensi protein ikan bandeng yang dipelihara selama penelitian Keterangan : A $(100 \%$ TK + 0\% TDK), B (75\% TK + 25\% TDK), C $(50 \% \mathrm{TK}+50 \% \mathrm{TDK}), \mathrm{D}(25 \% \mathrm{TK}+75 \%$ TDK).

Pada Gambar 6 terlihat bahwa retensi protein mengalami peningkatan pada perlakuan B $(75 \%$ TK $+25 \%$ TDK) dengan nilai $18,48 \pm 0,68 \%$, dibanding dengan perlakuan A $(100 \% \mathrm{TK}+0 \% \mathrm{TDK})$ yaitu $16,58 \pm 1,68 \%$, kemudian turun pada perlakuan $\mathrm{C}$ $(50 \%$ TK $+50 \%$ TDK $)$ yaitu $18,16 \pm 4,15 \%$ dan meningkat pada perlakuan D $(25 \% \mathrm{TK}+75 \% \mathrm{TDK})$ yaitu $18,48 \pm 3,77 \%$. Hasil analisis ragam menunjukkan bahwa pakan uji yang diberikan tidak memberikan pengaruh yang berbeda nyata terhadap retensi protein $(\mathrm{P}>0.05)$

Parameter kualitas air

Hasil pengukuran parameter kualitas air selama penelitian disajikan pada Tabel 2
Tabel 2. Parameter kualitas air yang diamati selama penelitian

\begin{tabular}{lcc}
\hline \multicolumn{1}{c}{ Parameter } & Satuan & Hasil \\
\hline Suhu & ${ }^{0} \mathrm{C}$ & $25-27$ \\
Salinitas & ppt & $23-27$ \\
pH & & $7-8$ \\
DO & mg/L & $4,5-6,6$ \\
$\mathrm{NH}_{3}$ & $\mathrm{mg} / \mathrm{L}$ & $0,014-0,041$ \\
\hline
\end{tabular}

\section{Pembahasan}

Tanaman kelor memiliki manfaat sebagai antibiotik, antitripanosamal, antiphasmodic, antiinflamasi, dan dapat menurunkan kolesterol (Fahey, 2005). Menurut Chumark et al. (2007) ekstrak daun kelor memberikan hipolipidemik dan hipokolestrol pada tikus yang diinduksi dengan adrenaline. Daun kelor segar memilik kekuataan antioksidan lebih banyak dibanding vitamin C (Funglie, 2001). Salah satu grup flavonoid yang dimiliki kelor yaitu kuersetin, dimana kuersetin memiliki kekuatan antioksidan $4-5$ kali lebih tinggi dibanding vitamin $\mathrm{C}$ dan vitamin $\mathrm{E}$ (Sutrisno, 2011).

Tumbuhan kelor merupakan salah satu tanaman yang dapat dimanfaatkan dalam bahan pembuatan pakan. Tanaman ini selain menjadi sumber vitamin dan asam amino yang baik dan memiliki kegunaan di bidang kesehatan sebagai obat. Salah satu jenis pakan herbal yang dikenal sebagai pengganti penggunaan antibiotik pemacu pertumbuhan (growth promoter antibiotic) adalah tepung daun kelor (Banjo, 2012).

Pertumbuhan adalah pertambahan ukuran panjang dan berat dalam suatu waktu akibat pembelahan sel secara mitosis. Ikan tidak mempunyai kebutuhan protein yang mutlak, namun untuk menunjang pertumbuhannya, ikan membutuhkan suatu campuran yang seimbang antara asam amino esensial dan non-esensial (Buwono, 2000). Kesesuaian jenis pakan sangat mempengaruhi suatu organisme untuk dapat bertahan hidup, tumbuh, dan berkembang biak (Gilangsari, 2000).

Pertumbuhan mutlak yang baik yaitu pada pakan perlakuan D $(25 \% \mathrm{TK}+75 \% \mathrm{TDK})$ juga dapat dipengaruhi tingkat konsumsi pakan yang tinggi yaitu sebesar 164,39 $\pm 2,63 \%$ dan nilai konversi pakan yang rendah yaitu sebesar $2,75 \pm 0,55$. Sudarman (1988) menyatakan bahwa kecepatan pertumbuhan tergantung pada jumlah pakan yang dikonsumsi dan kemampuan organisme memanfaatkan pakan. 
Tingginya pertumbuhan ikan bandeng didukung kandungan asam amino yang terdapat dalam pakan. Paisey (2009) menyatakan asam amino merupakan bagian dari protein yang berfungsi memperbaiki jaringan dan organ tubuh yang digunakan sebagai sumber energi pada proses metabolisme. Selain itu, asam amino merupakan salah satu penyusun protein, apabila terjadi kekurangan asam amino esensial maka akan terjadi ketidaksempurnaan sehingga sistem pertumbuhan akan terganngu dan tidak berjalan maksimal.

Ikan akan tumbuh apabila nutrisi pakan yang dicerna dan diserap oleh tubuh ikan lebih besar dari jumlah yang diperlukan untuk memelihara tubuhnya (Lovell, 1989). Hal ini akan terjadi apabila faktor pendukungnya dalam keadaan optimal, berbeda halnya apabila faktor pendukungnya misalnya kualitas air berada dibawah batas yang ditolerir oleh ikan maka pakan yang dimakan hanya digunakan untuk mempertahankan diri untuk hidup tidak untuk tumbuh dan berkembang. Cortez-Jacinto et al. (2005) menjelaskan bahwa laju pertumbuhan mutlak dan laju pertumbuhan harian berkaitan erat dengan berat tubuh yang berasal dari pakan yang dikonsumsi, karena pakan yang dikonsumsi oleh ikan digunakan untuk pertumbuhan.

Hasil penelitian ini menunjukkan bahwa substitusi pemberian pakan pada perlakuan D $(25 \%$ TK $+75 \%$ TDK) memberikan pertumbuhan mutlak yang tinggi yaitu $61,34 \pm 11,20 \mathrm{~g}$, dan yang rendah pada perlakuan A $(100 \% \mathrm{TK}+0 \% \mathrm{TDK})$. Selain itu didukung pula oleh nilai rasio konversi pakan pada perlakuan D $(25 \% \mathrm{TK}+75 \% \mathrm{TDK})$ yang paling rendah yaitu $2,75 \pm 0,55$. Pertumbuhan mutlak dalam penelitian ini lebih tinggi dibanding dengan pertumbuhan mutlak ikan bandeng yang diberi pakan bungkil biji kapuk hasil fermentasi yaitu sebesar 0,70 - 2,79 g (Sakinah, 2017). Hal ini menunjukkan bahwa pakan tepung daun kelor yang dikonsumsi termanfaatkan dengan baik untuk pertumbuhan. Hal ini disebabkan karena daun kelor mengandung vitamin dan mineral yang sangat penting untuk pertumbuhan dan perkembangan. Pemberian pakan substitusi tepung kedelai dengan tepung daun kelor tidak memberikan pengaruh yang berbeda nyata $\mathrm{P}>$ 0,05 pada pertumbuhan ikan bandeng tetapi tepung daun kelor bisa menggantikan keberadaan tepung kedelai dalam pakan sampai dengan $75 \%$ kandungan daun kelor. Meningkatnya pertumbuhan didukung juga dengan kandungan asam amino esensial lisin dalam pakan yang berasal dari tepung daun kelor.

Hasil penelitian ini juga menunjukkan nilai konversi pakan yang terbaik adalah $2,75 \pm 0,55 \%$ terdapat pada perlakuan D (75\% TDK $+25 \%$ TK ). Santoso dan Veroka (2011) menyatakan bahwa nilai koefisien pakan berbanding terbalik dengan konversi pakan dan berbanding lurus dengan pertambahan berat tubuh ikan, dimana semakin tinggi nilai efisiensi pakan maka nilai konversi pakan semakin rendah sehingga ikan semakin efisien memanfaatkan pakan yang dikonsumsi untuk pertumbuhan. Barrows dan Hardy (2001) menjelaskan bahwa nilai rasio konversi pakan dipengaruhi oleh protein pakan, protein pakan yang sesuai dengan kebutuhan nutrisi ikan mengakibatkan pemberian pakan efisien. Besar kecilnya nilai efisiensi pakan dipengaruhi juga oleh beberapa faktor seperti kepadatan, berat setiap individu, umur, kualitas air, cara pemberian pakan serta frekuensi pemberian pakan (Setiawati et al., 2013).

Tingkat kelangsungan hidup ikan bandeng yang diberi pakan substitusi tepung kedelai dengan tepung daun kelor berkisar 96,67 - 100\%, dimana pada perlakuan B, C dan D mencapai $100 \%$, sedangkan perlakuan A 96,67\%. Hasil tersebut memperlihatkan bahwa ikan bandeng sangat menyukai pakan tepung daun kelor ini dibuktikan dengan tingginya nilai konsumsi pakan yaitu $164,39 \pm 2,63$ g. Sakinah (2017) mendapatkan kelangsungan hidup ikan bandeng yang diberi pakan komersil berkisar 7090\%. Tingginya kelangsungan hidup ikan bandeng yang diberi pakan tepung daun kelor diduga disebabkan beberapa kandungan daun kelor seperti sistin yang berfungsi sebagai antioksidan dalam melindungi tubuh terhadap radiasi dan polusi. Kelor juga mengandung lisin yang berfungsi meningkatkan keseimbangan nutrisi yang mengurangi pertumbuhan virus. Selain itu juga tingginya kelangsungan hidup diduga disebabkan kualitas air dalam akuarium masih dalam kisaran optimal untuk hidup ikan bandeng.

Retensi protein adalah sejumlah protein yang berasal dari pakan yang terkonversi menjadi protein yang tersimpan ke dalam tubuh ikan. Retensi protein tertinggi didapatkan pada perlakuan B $(75 \% \mathrm{TK}+$ $25 \%$ TDK) yaitu sebesar $18,48 \pm 0,68 \%$, kemudian diikuti perlakuan D $(25 \% \mathrm{TK}+75 \% \mathrm{TDK})$ yaitu sebesar $18,25 \pm 3,77 \%$, perlakuan C $(50 \% \mathrm{TDk}+$ $50 \%$ TDK) yaitu sebesar 18,16 $\pm 4,15 \%$, dan terendah didapatkan pada perlakuan A $(100 \% \mathrm{TK}+$ 
$0 \%$ TDK) yaitu sebesar $16,58 \pm 1,68 \%$. Nilai retensi protein pada perlakuan B tinggi karena ikan lebih mampu mengonversi protein pakan menjadi protein yang tersimpan dalam tubuhnya dibandingkan dengan ikan pada perlakuan lainnya. Maynard et al. (1979) menyatakan bahwa kecernaan merupakan bagian pakan yang dikonsumsi, tidak dikeluarkan menjadi feses dan retensi protein merupakan salah satu kecernaan protein. Hasil analisis ragam menunjukkan bahwa perlakuan tidak memberikan pengaruh yang berbeda nyata terhadap retensi protein. Hal ini dikarenakan setiap perlakuan memiliki tingkat retensi protein yang relatif sama, sehingga memberikan respon yang sama pula terhadap hewan uji. Hal ini diduga karena kandungan protein pakan yang digunakan yang dihasilkan masih dalam rentang layak untuk kebutuhan ikan bandeng yaitu 30-40\% (Pascual, 1984). Hasil analisis proksimat pakan uji pada penelitian ini menunjukkan kandungan proteinnya berkisar antara 35,66 $38,38 \%$.

Kualitas protein ditentukan oleh jenis dan nilai asam amino yang dikandungnya. Protein yang memiliki mutu tinggi adalah protein yang mengandung semau jenis asam amino dalam jumlah yang sesuai untuk kebutuhan. Asam amino merupakan bagian dari protein yang berfungsi memperbaiki jaringan dan organ tubuh yang digunakan sebagai sumber energi pada metabolisme (Almatsier, 2006).

Kualitas air mempunyai peranan penting sebagai pendukung kelangsungan hidup ikan bandeng. Berdasarkan Tabel 2, pengukuran parameter kualitas air yang terdiri dari suhu, salinitas, $\mathrm{pH}$, dan ammonia masing-masing menunjukkan nilai yang berada pada kisaran optimum. Hasil penelitian menunjukkan bahwa kualitas air layak untuk pemeliharaan ikan bandeng, hal ini terbukti masih tingginya kelangsungan hidup. Kordi (2005) menyatakan bahwa bandeng hidup dan tumbuh pada kisaran salinitas $0-40$ ppt, pH $7-8,5$, suhu $25-32{ }^{\circ} \mathrm{C}$, ammonia $<0,1 \mathrm{mg} / \mathrm{L}$. Konsentrasi oksigen terlarut untuk kehidupan dan pertumbuhan ikan bandeng sudah cukup baik >3 mg/L (Deptan, 2000).

\section{KESIMPULAN}

Berdasarkan hasil penelitian dan pembahasan disimpulkan bahwa substitusi tepung kedelai dengan tepung daun kelor memberikan pengaruh yang sama terhadap pertumbuhan mutlak, laju pertumbuhan harian, retensi protein, tetapi memberikan pengaruh yang berbeda terhadap konsumsi pakan.

Pertumbuhan mutlak yang didapatkan pada penelitian ini berkisar antara 52,22 - 61,34 g, laju pertumbuhan harian berkisar 3,13-3,32\%, tingkat kelangsungan hidup berkisar 96,67 $-100 \%$, rasio konversi pakan berkisar 2,75 - 2,81, efisiensi pakan berkisar 35,79 - 37,42\%, konsumsi pakan berkisar $145,69-164,39 \mathrm{~g}$, retensi protein berkisar 16,58 $18,48 \%$.

\section{DAFTAR PUSTAKA}

Almatsier. 2006. Prinsip Dasar Ilmu Gizi. Gramedia Pustaka Utama. Jakarta.

Banjo OS. 2012. Growth and Performance as Affected by Inclusion of Moringa oleifera Leaf Meal in Broiler Chicken Diet. J. Biol. Agric. Healthcare 2: 35-38.

Barrows FT, Hardy RW. 2001. Nutrition and Feeding. In: Wedemeyer, G (Eds). Fish Hatchery Management. Second Edition. Maryland. American Fisheries Society. Bethesda. pp 483-559.

Bores GE, Cerecedo RC, Meza SR, Yee AG. 2006. Partial Repleacment of Red Crab (Pleuroncodes planipes) Meal for Fish Meal in Practical Diets for the White Shrimp (Litopeneus vannamei). Effect on Growth and Vivo Digestibility. Aquaculture $29: 67-71$.

Buwono IB. 2000. Kebutuhan Asam Amino Esensial dalam Ransum Ikan. Yogyakarta: Kanisius.

Chumark P, Khunawat P, Sanvarinda Y, Phornchirasilp S, Morales NP, Phivthong-Ngam L, Klai-upsorn SP. 2008. The in vitro and ex vivo antioxidant properties, hypolipidaemic and antiatherosclerotic activities of water extract of Moringa oleifera Lam. leaves. J. Ethnopharmacol 116: 439-446.

Corez-Jacinto EH, Villareal-Colmenares LE, CrusSuarez, Civera-Cercedo R, Nolascosoria H, Hernandes-Llamas A. 2005. Effect of Different Ditery Protein and Lipid Levels on Growth and Survival of Juvenile Australia RedClaw Crayfish (Cherax quadricarinatus). Agriculture

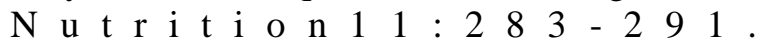
Departemen Pertanian. 2000. Pengelolaan Kualitas Air Tambak Bandeng. Samarinda: Lembar 
Informasi Pertanian, Loka Pengkajian Teknologi.

Fahey JW. 2005. Moringa oleifera: A Review of the Medicinal Evidence for its Nutritional, Therapeutic and Prophylactic Properties. Trees for Life Journal 1: 5 .

Funglie. 2001. The Moringa Tree. The Multiple Atributes of Moringa, EWS. Dakar, Senegal.

Gilangsari ER. 2000. Karakter Kuantitatif Ikan Patin Hibrida antara P. Hypophthalmus Betina dengan $P$. nusatus Jantan pada Fase Pembesaran. Fakultas Perikanan dan Ilmu Kelautan IPB.

Halver JE. 1989. Fish Nutrition 2. Academic Press inc.713pp.

Kordi G. 2005. Pengelolaan Kualitas Air. Jakarta: Rineka Cipta. pp1-32

Lovell RT. 1989. Nutrition and Feeding of Fish.Van Nostrand Reinhold. New York: Auburn University. 217 p.

Maynard LA, Loosli JK, Hintz HF, Warner RG. 1979. Animal Nutrition. Seventh Edition. New Delhi: McGraw-Hill Book Company. 602 pp.

NRC (National Research Council). 1977. Nutrition requirement of warm water fishes. Washington DC: National Academic Press.

Pamijati. 2009. Pengaruh Ekstrak Daun Selasih (Ocimum basilicum linn) terhadap Mutu Kesegaran Ikan Bandeng (Chanos chanos) selama Penyimpanan Dingin. Semarang. Universitas Diponegoro.

Paisey AS. 2009. Pemanfaatan Tepung Bungkil Kedelai dalam Pakan Benih Ikan Patin [Tesis]. Bogor. Institut Pertanian Bogor.

Priyadi A, Azwar ZI, Subamia IW, Hem S. 2008. Pemanfaatan Maggot Sebagai Pengganti Tepung Ikan Dalam Pakan Buatan Untuk Benih Ikan Balashark (Balanthiocheilus melanopterus Bleeker). Depok: Loka Riset Budidaya Ikan Hias Air Tawar.

Pascual FP. 1984. The Energy-Protein Requirement of Chanos chanos Fingerlings. Poster paper presented during the International Symposium on Feeding and Nutrition in Fish. UK: University of Aberdeen.

Puycha K, Bundit Y, Siripavee C, Sutee W, Pornthep N, Pattama W. 2017. Effect of Moringa (Moringa oleifera) Leaf Supplementation on Growth Performance and Feed Utilization of
Bocourti's Catfish (Pangasius bocourti). Agriculture and Natural Resources 51: 286-291. Santoso L, Veroka S. 2011. Pemanfaatan Biji Koro Benguk (Mucuna prurient) sebagai Substitusi Tepung Kedelai pada Pakan Benih Ikan Patin Siam (Pangasius hypophthalmus). Berkala Perikanan Terubuk 3(2):9-16.

Sakinah S. 2017. Pengaruh Substitusi Tepung Bungkil Kedelai dengan Tepung Bungkil Biji Kapuk Hasil Fermentasi dalam Pakan Buatan Juvenil Ikan Bandeng (Chanos chanos Forskall) [Tesis]. Kendari. Ilmu Perikanan, Program Pascasarajana Universitas Halu Oleo.

Setiawati JE, Tarsim YT, Adiputra, Hudaidah S. 2013. Pengaruh Penambahan Probiotik pada Pakan dengan Dosis Berbeda terhadap Pertumbuhan, Kelulushidupan, Efisiensi Pakan dan Retensi Protein Ikan Patin (Pangasius hypophthalmus). Jurnal Rekayasa dan Teknologi Budidaya Perairan 1(2):

Soltanzadeh S. 2015. Growth Performance, Body Composition, Hematological, and Serum Biochemical Responses of Beluga (Huso huso) Juveniles to Different Dietary Inclusion Levels of Faba Bean (Vicial faba) Meal. Aquaculture.

Sudarman. 1988. Budidaya Udang Windu. Pembesaran di Tambak. Surabaya: Agricultural Techinal.

Suprayudi MA. 2010. Pengembangan Penggunaan Bahan Baku Lokal untuk Pakan Ikan/Udang: Status Terkini dan Prospeknya. Makalah disajikan pada Semi-Loka Nutrisi dan Teknologi Pakan Ikan /Udang. Bogor 26 Okteober 2010.n Badan Litbang Kelautan dan Perikanan, KKP bekersama dengan ISPIKANI. Jakarta.

Sutrisno. 2011. Efek Pemberian Ekstrak Daun Kelor (Moringa oleifera) Meningkatkan Apoptosis Pada Sel Epitel Kolon Tikus (Ratus norvegius) Wistar yang di Induksi 7,12 Dimetilbenz $(\alpha)$ Antrasen (DMBA). Malang. Universitas Brawijaya.

Takeuchi T. 1988. Laboratory work chemical evaluation of dietary nutriens. In: Wata-nabe T (Editor). Fish nutrition and mariculture.

Watanabe T. 1988. Fish Nutrition andMariculture. Departement of Aquatic Bioscience. Tokyo: University of Fisheies. JICA233 pp. 